\title{
PENGARUH PENGGUNAAN SISTEM INFORMASI AKUNTANSI, TEKNOLOGI INFORMASI, PENGENDALIAN INTERNAL DAN KUALITAS SUMBER DAYA MANUSIA TERHADAP KUALITAS LAPORAN KEUANGAN
}

\author{
Helmi Prila Aldino ${ }^{1)}$, Renil Septiano ${ }^{2)}$ \\ "Sekolah Tinggi Ilmu Ekonomi "KBP" \\ helmiprillaaldino@akbpstie.ac.id \\ renilseptiano@akbpstie.ac.id
}

\begin{abstract}
Abstrak : Tujuan penelitian ini adalah untuk mengetahui pengaruh penggunaan sistem informasi akuntansi, teknologi informasi, Sistem Pengendalian Intern dan Kualitas Sumber Daya Manusia terhadap kualitas laporan keuangan pada instansi pemerintah kota Padang. Populasi dalam penelitian ini adalah seluruh pegawai keuangan pada instansi Pemerintah Kota Padang. Menggunakan teknik convenience sampling diterapkan untuk menentukan sampel. Sampel dalam penelitian ini adalah pegawai bagian keuangan pada instansi pemerintah kota Padang yang memenuhi kriteria. Jumlah sampel yang digunakan adalah 142 responden yang diambil berdasarkan kriteria yang telah ditentukan. Pengumpulan data dilakukan dengan menggunakan kuesioner yang diukur dengan skala Likert. Hasil penelitian menunjukkan bahwa sistem informasi akuntansi, teknologi informasi Sistem Pengendalian Intern dan Kualitas Sumber Daya Manusia berpengaruh positif dan signifikan terhadap kualitas laporan keuangan yang ditunjukkan dengan nilai signifikan sebesar 0,00 ,
\end{abstract}

Kata Kunci : Sistem Informasi Akuntansi, Teknologi Informasi, Sistem Pengendalian Intern, Kualitas Sumber Daya Manusia dan Kualitas Laporan Keuangan

Abstract: The purpose of this study was to determine the effect of the use of accounting
information systems, information technology, Internal Control Systems and the Quality of Human
Resources on the quality of financial reports in Padang city government agencies. The population
in this study were all financial employees at Padang City Government agencies. Using convenience
sampling technique was applied to determine the sample. The sample in this study were employees
of the finance department at Padang city government agencies who met the criteria. The number of
samples used was 142 respondents who were taken based on predetermined criteria. Data was
collected by using a questionnaire measured by a Likert scale. The results showed that accounting
information systems, information technology Internal Control Systems and the Quality of Human
Resources had a positive and significant effect on the quality of financial reports, which was
indicated by a significant value of 0.00 ,

Keywords: Accounting Information Systems, Information Technology, Internal Control Systems, Quality of Human Resources and Quality of Financial Reports

\section{A. PENDAHULUAN}

Laporan keuangan berisi informasi tentang posisi keuangan dan hasil yang dicapai oleh anggaran selama tahun fiskal. Pemerintah Daerah diberi mandat dan wewenang untuk melakukan pengelolaan keuangan untuk daerah, sehingga harus bertanggung jawab atas semua mandat dan wewenang yang telah dilakukan, oleh standar pelaporan keuangan ditetapkan. Selain adanya standar akuntansi pemerintah sebagai acuan dalam menggunakan proses Perangkaian laporan keuangan haru dilakukan secara efesien dan juga akurat, tepat waktu dan tentunya data yang dihasilkan harus rill/akurat. Diperlukan suatu sistem yang dapat merangkul pencapaian tersebut, yaitu adanya dukungan teknologi informasi (Widarsono, 2017).

Operasional manajemen keuangan harus mendapatkan informasi yang lebih dalam mengenai laporan keuangan, sehingga dari publikasi laporan keuangan tersebut dapat berguna bagi pihak yang berkepentingan dan menjadi dasar pengambilan keputusan. Menurut Pernyataan Standar Akuntansi Keuangan No. 1 tahun 2015, Laporan Keuangan merupakan presentasi prosedural dari 
posisi keuangan dalam kinerja keuangan suatu entitas. Laporan ini menyatakan bahwa sejarah entitas terukur memiliki nilai yang berharga. Laporan keuangan adalah bagian dari proses pelaporan keuangan. Biasanya, laporan keuangan lengkap meliputi laporan keuangan, laporan laba rugi, laporan perubahan modal penuh, arus kas atau laporan register kas dan laporan lain yang merupakan bagian dari integritas laporan keuangan (Ernawati Fidyah Yuli, 2017).

Menurut Masiaga, (2019) Sistem informasi akuntansi merupakan pengaturan berbagai dokumen, alat komunikasi, eksekutif, dan berbagai laporan yang dirancang untuk mengubah data keuangan dari perusahaan atau organisasi menjadi informasi keuangan yang lebih baik dan Sistem informasi Akuntansi terdiri dari 3 indikator yaitu indikator relevan, kegunaan, dan prosedur.

Menurut Hanafiah \& Zulvia, (2018) Sistem Informasi Akuntansi sebagai sistem yang memproses data dan transaksi untuk menghasilkan informasi yang berguna untuk perencanaan, pengendalian, dan operasi bisnis. Sistem informasi akuntansi terdiri dari tiga subsistem yang dijelaskan oleh Hall (2009: 10), ketiga subsistem tersebut adalah:

a. Sistem Pemrosesan Transaksi Dapat memberikan dukungan untuk operasi setiap hari yang terdiri dari dokumen dan sinyal untuk pengguna yang terlibat dalam entitas.

b. Buku Besar / Sistem Pelaporan Keuangan Hasil dari sistem ini adalah laporan keuangan dalam bentuk laporan laba rugi, perubahan dalam laporan ekuitas, laporan posisi keuangan dan laporan lainnya.

\section{Sistem Informasi Akuntansi Terhadap Kualitas Laporan Keuangan}

Menurut Eveline, (2017) Sistem informasi akuntansi adalah sistem yang memproses data dan transaksi untuk menghasilkan informasi yang berguna untuk perencanaan, manajemen, dan bisnis. Untuk memungkinkan pembuat keputusan menghasilkan informasi yang mereka butuhkan, sistem informasi akuntansi mengumpulkan transaksi dan data lainnya, memasukkannya ke dalam sistem data, memproses dan menyimpan data untuk kebutuhan masa depan, Anda perlu membuat laporan dan informasi atau memungkinkan pengguna untuk melihat data yang tersimpan. Kontrol seluruh proses sehingga informasi yang dihasilkan akurat dan efisien. Menurut (Gafur, 2016) Pemanfaatan system informasi akuntansi keuangan berpengaruh signifikan terhadap kualitas laporan keuangan melalui internal audit, Karena system informasi akuntansi merupakan kemampuan system informasi untuk memberikan keyakinan bahwa informasi yang disajikan dalam laporan keuangan adalah benar atau valid, dan ketersediaan informasi bagi pembuat keputusan jika perlu sebelum informasi kehilangan kekuatan untuk mempengaruhi keputusan.

Menurut Masiaga, (2019) sistem informasi akuntansi adalah komponen yang terkait dengan pengumpulan, pemrosesan, penyimpanan dan penyebaran informasi untuk mendukung pengambilan keputusan dan pengawasan dalam suatu organisasi. Dalam Sistem informasi memerlukan aliran informasi. Hal ini disebabkan oleh keragaman kebutuhan informasi pengguna informasi. Sistem informasi juga mempengaruhi kinerja pemerintah daerah, yang terkait erat dengan sistem informasi akuntansi. Menurut Juwita, (2018), Sistem informasi akuntansi memiliki dampak positif dan signifikan terhadap kualitas laporan keuangan. Memberikan bukti empiris bahwa sistem informasi akuntansi pemerintah yang baik meningkatkan kualitas laporan keuangan. Kita kemudian dapat menyimpulkan bahwa sistem informasi akuntansi memiliki hubungan positif yang signifikan dengan kualitas laporan keuangan.

Berdasarkan dari sumber pada penelitian terdahulu seperti yang telah dijelaskan diatas bahwa dari hasil empat sumber penelitian menunjukkan berpengaruh signifikan terhadap Kualitas Laporan Keuangan, maka dapat diambil kesimpulan hipotesis sementara yaitu:

H1: Sistem Informasi Akuntansi Berpengaruh Terhadap Kualitas Laporan Keuangan.

\section{Teknologi Informasi terhadap Kualitas Laporan Keuangan}

Menurut Puspita, (2017) Teknologi informasi mempunyai andil yang besar untuk mencapai laporan keuangan yang berkualitas. Teknologi informasi berfungsi sebagai pemrosesan, penyimpanan informasi, dan penyebaran informasi. Peraturan Pemerintah Republik Indonesia Nomor 65 Tahun 2010 tentang Sistem Informasi Keuangan Daerah, menjelaskan bahwa untuk 
menindaklanjuti perencanaan pembangunan sesuai dengan prinsip-prinsip tata kelola yang efektif, pemerintah pusat dan pemerintah daerah wajib mengembangkan dan memanfaatkan kemajuan teknologi informasi untuk meningkatkan pengelolaan keuangan daerah, dan menyalurkan informasi keuangan daerah ke layanan publik. Menurut (Wahyuni, Fadah, \& Tobing, 2018) Pemanfaatan teknologi informasi berpengaruh terhadap kualitas laporan keuangan, artinya semakin dimanfaatkannya teknologi informasi maka laporan keuangan akan semakin berkualitas

Menurut Rifandi, (2019) Teknologi informasi adalah aplikasi untuk menggunakan SIKD oleh pemerintah daerah untuk dapat menggunakan semua jenis informasi dan teknologi komputer untuk memberikan informasi dan layanan pemerintah kepada publik. Penggunaan teknologi informasi dalam akuntansi dapat memengaruhi kepuasan pengguna dengan laporan keuangan karena kualitas, keakuratan, dan keakuratan data dalam laporan keuangan yang ditentukan. Menurut (Widarsono, 2017) pengaruh yang positif terhadap efektivitas penerapan teknologi informasi terhadap kualitas laporan keuangan.

Berdasarkan dari sumber pada penelitian terdahulu seperti yang telah dijelaskan diatas bahwa dari hasil empat sumber penelitian menunjukkan berpengaruh signifikan terhadap Kualitas Laporan Keuangan, maka dapat diambil kesimpulan hipotesis sementara yaitu:

H2: Teknologi informasi Berpengaruh Terhadap Kualitas Laporan Keuangan.

\section{Pengaruh Sistem Pengendalian Internal Terhadap Kualitas Laporan Keuangan}

Penelitian sebelumnya Eveline (2016) Pengolahan sesuai dengan kebutuhan dan situasi pengendalian internal yang baik menghidupkan semangat organisasi untuk melanjutkan upaya mempertahankan kualitas laporan keuangan. Pengendalian internal yang terintegrasi dari unit ke delegasi dapat membuat laporan keuangan yang berkualitas sesuai dengan harapan organisasi. Hal ini juga terbukti dari penelitian (Trisnawati, 2018) bahwa sistem pengendalian internal memiliki efek positif pada kualitas pelaporan keuangan.

Menurut Aditya \& Surjono (2018) membuat laporan keuangan untuk pemerintah, harus melalui proses dan fase diatur oleh sistem akuntansi pemerintah. Secara transparan serta dapat dipertanggung jawaban yang dilakukan oleh manajemen keuangan. Hal ini dapat dilakukan jika pemerintah daerah dapat membangun, mengoperasikan dan memelihara sistem pengendalian internal yang sesuai.

Menurut Nunung Suhaeti, Suhendar (2015) Sebuah proses integral dalam kepemimpinan dan perilaku yang berkelanjutan dan kegiatan dari seluruh karyawan hak untuk memberikan kredibilitas mencapai tujuan organisasi melalui efektif dan efisien antara sistem pengendalian internal dan kualitas pelaporan keuangan berdampak signifikan penelitian ini.

H3: Sistem Pengendalian Internal berpengaruh terhadap kualitas Laporan Keuangan

\section{Pengaruh Kualitas Sumber Daya Manusia Terhadap Kualitas Laporan Keuangan}

Menurut Trisnawati (2018) Laporan keuangan yang dihasilkan oleh pemerintah daerah semakin baik apabila pengolahan SDM juga baik. Menurut Taman (2017) Kualitas sumber daya manusia ialah kemampuan karyawan untuk berurusan dengan pengetahuan, keterampilan dan sikap dalam menyelesaikan tugas. Dalam menyelesaikan pekerjaan secara efisien dan efektif juga mendukung ketepatan waktu pelaporan keuangan membutuhkan sumber daya manusia yang kompeten.

Menurut Eveline (2016) sumber daya manusia dengan keterampilan akuntansi yang baik dalam menguasai proses penyusunan laporan keuangan sampai publikasi. Artinya, SDM dapat mengontrol proses dan menjaga proses sesuai dengan aturan. Hal ini memungkinkan SDM untuk melakukan kontrol internal dalam persiapan, penyusunan dan penyajian laporan keuangan. Tidak memiliki dampak postif terhadap kualitas laporan keuangan dari hasil yang dapat disimpulkan tersebut Artinya, mereka benar-benar dapat melatih sumber daya manusia yang kurang mampu dan mengawasi pelaksanaan laporan keuangan. Kualitas sumber daya manusia telah terbukti tidak mempengaruhi kualitas laporan keuangan,

H4: Kualitas SDM Berpengaruh Positif Terhadap Kualitas Laporan Keuangan. 


\section{B. METODE PENELITIAN}

Penelitian ini menguji tentang apakah Penggunaan system informasi akuntansi, teknologi informasi, sistem pengendalian internal dan sumber daya manusia berpengaruh terhadap kualitas laporan keuangan pada instansi pemerintah kota Padang, maka penelitian ini bisa di masukan dalam penelitian kuantitatif. Adapun data yang dipakai untuk penelitian ini merupakan data primer dengan memakai skala likert dalam pengukuran koesioner.

Penelitian ini dijalankan dengan mengambil beberapa sampel pegawai bagian keuangan pada instansi pemerintah kota Padang. Populasi seluruh pegawai bagian keuangan di instansi pemerintah kota Padang sebanyak 142 responden menggunakan koesioner sebagai alat ukur dalam menggabungkan data yang pasti, untuk menjabarkan keterkaitan antara satu variabel dengan variabel lainnya dan penelitian ini memakai kedekatan kuantitatif.

Sampel dan populasi untuk penelitian ini adalah pegawai bagian keuangan pada instansi pemerintah kota padang dan seluruh pegawai bagian keuangan di instansi pemerintah kota Padang yang menjadi responden dalam penelitian ini ada 52 Instansi Pemerintah Kota Padang.

Adapun kuesioner yang telah di sebarkan adalah sebanyak 184 kuesioner yang kembali hanya sebnyak 142 kuesioner, sebagian tidak ada memberikan tanggapan dan kuesioner tidak di kembalikan dan memberikan alasan hilang, sebagian pegawai bagian keuangan tidak masuk kerja selama proses penelitian. Maka dengan demikian teknik pengambilan sampel dalam dalam penelitian ini adalah menggunakan teknik convenience sampling merupakan salah satu teknik sampling non probability sampling dimana informasi yang dikumpulkan dari anggota populasi yang bersedia memberikan informasinya.(Sugiyono, 2016)

Tabel 1

Defenisi Operasional Variabel

\begin{tabular}{|c|c|c|c|}
\hline No & Variabel & Pengertian & Indikator \\
\hline 1 & $\begin{array}{l}\text { Kualitas } \\
\text { Laporan } \\
\text { Keuangan } \\
(Y)\end{array}$ & $\begin{array}{l}\text { Kualitas Laporan keuangan yang } \\
\text { dihasilkan dari penerapan SAP } \\
\text { berbasis akrual } \\
\text { Permendagri No.64 tahun } 2013 \\
\text { tentang penerapan standar } \\
\text { akuntansi pemerintahan berbasis } \\
\text { akrual pada pemerintah daerah, } \\
\text { dimaksudkan untuk memberi } \\
\text { manfaat lebih baik bagi para } \\
\text { pemangku pentingan } \\
\text { (pengguna), yaitu pengguna } \\
\text { laporan keuangan pemerintah } \\
\text { maupun pemeriksa laporan } \\
\text { keuangan pemerintah, } \\
\text { dibandingkan dengan biaya yang } \\
\text { dikeluarkan(Nadir \& Hasyim, } \\
\text { 2018) }\end{array}$ & $\begin{array}{l}\text { 1. Memiliki Karakteristik yang } \\
\text { relevan, tepat waktu, dan } \\
\text { lengkap dalam memberikan } \\
\text { informasi yang dapat } \\
\text { mengoreksi ekspetasi dimasa } \\
\text { lalu. } \\
\text { 2. Memiliki Karakteristik Laporan } \\
\text { Keuangan yang bersifat andal, } \\
\text { jujur, dan material dalam } \\
\text { menyajikan informasi yang } \\
\text { diarahkan untuk kebutuhan } \\
\text { umum dan tidak berpihak pada } \\
\text { kebutuhan khusus yang dapat } \\
\text { diuji. } \\
\text { 3. Laporan Keuangan dapat } \\
\text { dibandingkan dengan laporan } \\
\text { keuangan periode sebelumnya. } \\
\text { 4. Laporan Keuangan yang telah } \\
\text { disajikan dapat dipahami oleh } \\
\text { pengguna secara jelas. }\end{array}$ \\
\hline 2 & $\begin{array}{l}\text { Sistem } \\
\text { Informasi } \\
\text { Akuntansi } \\
\text { (X1) }\end{array}$ & $\begin{array}{l}\text { Sistem Informasi merupakan } \\
\text { sekumpulan komponen yang } \\
\text { saling } \\
\text { mengumpulkan, berhubungan } \\
\text { menyimpan dan mendistribusikan } \\
\text { informasi nuntuk menunjang }\end{array}$ & $\begin{array}{l}\text { 1. Sistem Informasi Akuntansi } \\
\text { dapat dimanfaatkan dan } \\
\text { dikuasai pada teknologi } \\
\text { Komputerisasi } \\
\text { kemampuan dasar bagi tim }\end{array}$ \\
\hline
\end{tabular}




\begin{tabular}{|c|c|c|c|c|}
\hline No & Variabel & Pengertian & & Indikator \\
\hline & & $\begin{array}{lc}\text { pengambilan } & \text { keputusan } \\
\text { pengawasan } & \text { dalam } \\
\text { organisasi(Masiaga, 2019) }\end{array}$ & $\begin{array}{r}\text { dan } \\
\text { suatu }\end{array}$ & $\begin{array}{l}\text { penyusun laporan. } \\
\text { 2. Sistem Informasi Akuntansi } \\
\text { berhubungan dengan teknologi } \\
\text { 3. kesuksesan pelaksanaan system } \\
\text { pelaporan keuangan dengan } \\
\text { mempermudah dan } \\
\text { mempercepat serta menciptakan } \\
\text { keakuratan hasil, berupa laporan } \\
\text { keuangan berpengaruh positif } \\
\text { terhadap ketepatan waktu. } \\
\text { 4. Sistem Informasi Akuntansi } \\
\text { memanfaatkan teknologi } \\
\text { informasi membuka peluang } \\
\text { untuk mengakses, mengelola, } \\
\text { dan mendayagunakan informasi } \\
\text { keuangan secara cepat dan } \\
\text { akurat dalam melaksanakan } \\
\text { tugas yang cukup. }\end{array}$ \\
\hline
\end{tabular}

\begin{tabular}{ccl}
\hline Teknologi & Peran Teknologi Informasi (TI) \\
Informasi & tidak diragukan lagi penting dalam \\
(X2) & perdagangan dan bisnis ini arena \\
& hadir. Dengan teknologi \\
& informasi, bisnis sekarang dapat \\
& menyebarkan informasi dan berita \\
& di berbagai acara, untuk \\
& berinovasi segar produk/jasa, \\
& untuk memahami prospek bisnis, \\
& serta untuk menyusun strategi \\
& bisnis yang kreatif dan \\
& fleksibel(Saeidi et al., 2018).
\end{tabular}

\begin{tabular}{lllrl}
\hline 4 & Sistem & Sistem pengendalian & internal & 1. Lingkungan pengendalian \\
& Pengendalian & merupakan tanggung & jawab & 2. Penilaian resiko \\
Internal (X3) & manajemen & sebuah & 3. Kegiatan pengendalian \\
& & organisasi.Tanggung & jawab & 4. Informasi dan komunikasi \\
& manajemen meliputi pembuatan & & kan \\
\hline
\end{tabular}




\begin{tabular}{|c|c|c|c|}
\hline No & Variabel & Pengertian & Indikator \\
\hline & & $\begin{array}{l}\text { dan pemeliharaannya.Sistem } \\
\text { pengendalian internal harus dibuat } \\
\text { secara memadai, artinya harus } \\
\text { sesuai dengan kebutuhan } \\
\text { organisasi yang menggunakannya } \\
\text { (Zulvia, 2015) }\end{array}$ & Pemantaun \\
\hline 5 & $\begin{array}{l}\text { Kualitas } \\
\text { Sumber } \\
\text { Daya } \\
\text { Manusia }\end{array}$ & 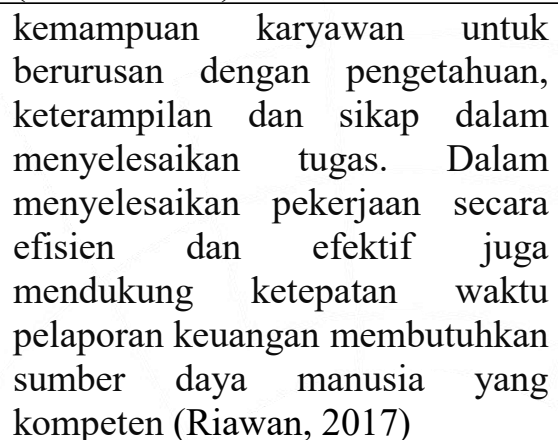 & $\begin{array}{l}\text { 1. Pengetahuan } \\
\text { 2. Pelaksanaan } \\
\text { 3. Pelatihan } \\
\text { 4. Pengalaman }\end{array}$ \\
\hline
\end{tabular}

\section{HASIL DAN PEMBAHASAN}

Ada beberapa pengujian data yang digunakan dalam penelitian ini sebagai berikut, uji validitas, uji reabilitas, uji normalitas, uji multikolineritas, uji heteroskedastisitas, uji regresi linear berganda, uji T, dan uji R Square. Adapun persamaan uji regresi linear berganda sebagai berikut: $Y$ $=\mathrm{a}+\mathrm{b}_{1}, \mathrm{X}_{1}+\mathrm{b}^{2}, \mathrm{X}_{2}+\mathrm{e}$

\section{Uji Validitas Sistem Informasi Akuntansi}

hasil perhitungan yang dilakukan pada 5 item pernyataan yang digunakan untuk variable X1, (Sistem Informasi Akuntansi) maka dapat disimpulkan bahwa dari pernyataan diatas dapat di nyatakan valid, karena $r$ hitung $>$ dari nilai $r$ table, adapun nilai $r$ table yaitu 0,1648 , dengan signifikan $<0,05$.

\section{Uji Validitas Teknologi Informasi}

hasil perhitungan yang di lakukan pada 8 item pernyataan yang di gunakan untuk variable X2, (Teknologi Informasi) maka dapat disimpulkan bahwa dari 8 pernyataan di atas dapat di nyatakan valid, karena nilai $r$ hitung $>$ dari nilai $r$ table, adapun nilai $r$ table yaitu sebesar 0,1648 dengan signifikan $<0,05$.

\section{Uji Validitas Sistem Pengendalian Internal}

Dari table di atas, Untuk menentukan $r$ tabel bisa menggunakan rumus $\mathrm{df}=\mathrm{N}-2, \mathrm{DF}=$ 142-2, $\mathrm{df}=140 . \mathrm{r}$ tabel dengan $\mathrm{df}=140$ dengan tingkat signifikansi uji 2 arah sebesar 0.05 adalah sebesar 0.1648. Maka semua indikator instrumen Sistem Pengendalian Internal dinyatakan valid karena corrected item-total pada table 2 lebih besar dari $r$ tabel.

\section{Kualitas Sumber Daya Manusia}

Untuk semua indikator instrumen kualitas sumber daya manusia pada tabel 4.3 besar dari pada $r$ tabel (0.1648). Maka semua indikator instrumen kualitas sumber daya manusia dinyatakan valid.

\section{Kualitas Laporan Keuangan}

Hasil perhitungan yang dilakukan pada 9 pernyataan yang digunakan untuk variable $\mathrm{Y}$, (Kualitas Laporan Keuangan) maka dapat disimpulkan bahwa dari 9 pernyataan diatas dapat 
dinyatakan valid, karena nilai $r$ hitung $>$ dari nilai $r$ table, adapun nilai $r$ table yaitu sebesar 0,1648 , dengan tingkat signifikan $<0,05$.

Tabel 7

Hasil uji realibilitas

\begin{tabular}{|c|c|c|c|}
\hline & Variabel & Cronbach's Alpha & Keterangan \\
\hline 1 & Sistem Informasi Akuntansi & 0,835 & Sangat Realibel \\
\hline 2 & Teknologi Informasi & 0,849 & Sangat Realibel \\
\hline 3 & Sistem Pengendalian Internal & 0,899 & Sangat Realibel \\
\hline 4 & Kualitas Sumber Daya Manusia & 0,918 & Sangat Realibel \\
\hline 5 & Kauliats Laporan Keuangan & 0,857 & Sangat Realibel \\
\hline
\end{tabular}

Menurut Priyatno (2014) realibilitas kurang dari 0,6 adalah kurang baik, sedangkan 0,7 dapat diterima dan diatas 0,8 adalah baik. Dilihat dari cronbach's alpha Sistem Informasi Akuntansi, Teknologi Informasi, Sistem Pengendalian Internal, Kualitas Sumber Daya Manusia dan Kualitas Laporan Keungan besar dari 0.8 semua indikator instrumen dinyatakan baik atau sangat realibel.

Tabel 8

Hasil Uji Normalitas

One-Sample Kolmogorov-Smirnov Test

\begin{tabular}{llr} 
& & $\begin{array}{c}\text { Unstandardize } \\
\text { d Residual }\end{array}$ \\
\hline $\mathrm{N}$ & Mean & 142 \\
\hline Normal Parameters & a,b &, 0000000 \\
\cline { 2 - 3 } & Std. Deviation & 3,16053945 \\
\hline Most Extreme & Absolute &, 070 \\
\cline { 2 - 3 } Differences & Positive &, 066 \\
\cline { 2 - 3 } & Negative &,- 070 \\
\hline Test Statistic & &, 070 \\
\hline Asymp. Sig. (2-tailed) & &, $087^{\mathrm{c}}$ \\
\hline
\end{tabular}
a. Test distribution is Normal.
b. Calculated from data.
c. Lilliefors Significance Correction.

Sumber: hasil olahan data spss 23 (2018)

Dari hasil pengolahan data pada tabel diperoleh besarnya nilai test statistis adalah 0.070 dan signifikan pada 0.087 . Data residual berdistribusi normal jika Nilai signifikasi lebih besar dari 0, 05 maka $\mathrm{H} 0$ diterima.

Tabel 9

Hasil Uji Multikolineritas

\begin{tabular}{|c|c|c|c|c|c|c|c|}
\hline \multicolumn{8}{|c|}{ Coefficients $^{\mathrm{a}}$} \\
\hline \multirow[b]{2}{*}{ Model } & $\begin{array}{l}\text { Unstanc } \\
\text { Coeffi }\end{array}$ & $\begin{array}{l}\text { dized } \\
\text { ents }\end{array}$ & $\begin{array}{l}\text { Standardized } \\
\text { Coefficients }\end{array}$ & & & $\begin{array}{l}\text { Colline } \\
\text { Statist }\end{array}$ & \\
\hline & B & $\begin{array}{l}\text { Std. } \\
\text { Error }\end{array}$ & Beta & $\mathrm{t}$ & Sig. & Tolerance & VIF \\
\hline $1 \quad$ (Constant) & 11,557 & 2,797 & & 4,132 &, 000 & & \\
\hline
\end{tabular}




\begin{tabular}{llllllll}
\hline $\begin{array}{l}\text { Sistem Informasi } \\
\text { Akuntansi X1 }\end{array}$ &, 485 &, 138 &, 283 & 3,518 &, 001 &, 676 & 1,479 \\
\hline $\begin{array}{l}\text { Teknologi } \\
\text { Informasi X2 }\end{array}$ & .280 & .083 & .282 & 3.371 & .001 & .690 & 1.450 \\
\hline $\begin{array}{l}\text { Sistem } \\
\begin{array}{l}\text { Pengendalian } \\
\text { Internal X3 }\end{array}\end{array}$ &, 320 &, 087 &, 331 & 3,679 &, 000 &, 542 & 1,845 \\
$\begin{array}{l}\text { Kualitas Sumber } \\
\text { Daya Manusia X4 }\end{array}$ &, 124 &, 083 &, 130 & 1,492 &, 138 &, 573 & 1,744 \\
\hline
\end{tabular}

a. Dependent Variable: Kualitas Laporan Keuangan Y

Sumber: hasil olahan data spss 23 (2018)

Uji moltikolineritas bertujuan untuk melihat korelasi antar variable independen (X) apabila terdapat multikolineritas yang signifikan antar variable independen, maka harus dieliminasi dari analisis regresi berganda. Uji multikolineritas dapat di uji dengan nilai VIF untuk masingmasing variable independen, ada ketentuan untuk bebas dari multikolineritas adalah apabila angka tolerence di atas 0,10 dan nilai VIF $<10$ maka dapat dikatakan tidak terjadi multikolineritas.

Tabel 10

Uji Heteroskeadastisitas

Coefficients ${ }^{\mathrm{a}}$

Coefficients $^{\mathbf{a}}$

\begin{tabular}{|c|c|c|c|c|c|}
\hline \multirow[b]{2}{*}{ Model } & \multicolumn{3}{|c|}{ Unstandardized Coefficients Standardized Coefficients } & \multirow[b]{2}{*}{$\mathrm{t}$} & \multirow[b]{2}{*}{ Sig. } \\
\hline & $\mathrm{B}$ & Std. Error & Beta & & \\
\hline 1 (Constant) & ,489 & 1,841 & & 266 & ,791 \\
\hline Sistem Informasi Akuntansi X1 &, 032 &, 091 & ,036 &, 353 &, 725 \\
\hline Teknologi Informasi X2 & .067 & .053 & .126 & 1.260 & .210 \\
\hline Sistem Pengendalian Internal X3 &,- 005 & 057 &,- 009 &,- 082 & ,934 \\
\hline Kualitas Sumber Daya Manusia X4 &, 041 &, 055 &, 084 &, 752 & 453 \\
\hline
\end{tabular}

a. Dependent Variable: Res

\section{Sumber hasil olahan data SPSS 22}

Uji heteroskedastisitas digunakan untuk melihat apakah dalam sebuah regresi terjadi ketidak samaan variable residual satu pengamatan ke pengamatan lainnya. Untuk medeteksi adanya gejala heteroskedastisitas maka menggunakan uji glejser yaitu apabila tingkat signifikan probabilitas $>0,05$ maka tidak terjadi heteroskedastisaitas dan pada uji grafik plot apabila tidak ada pola yang jelas, serta titik -titik menyebar di atas dan di bawah angka 0 pada sumb Y, maka tidak terjadi heteroskedastisitas.

Berdasarkan tabel di atas, maka dapat di ketahui bahwa nilai dari probabilitas signifikan variable Sistem Informasi Akuntansi (X1) sebesar 0,725, Teknologi Informasi (X2) sebasar 0,210, Sistem Pengendalian Internal (X3) sebesar 0,934 dan Kualitas Sumber Daya Manusia (X4) Sebesar 0,453 dalam hal ini signifikan variable X1, X2, X3 dan X4 > 0,05 jadi dapat disimpulkan model regresi ini tidak mengandung adanya heterokedastisitas.

Tabel 11

Hasil Uji Regresi Linear Berganda

\begin{tabular}{|c|c|c|c|c|c|}
\hline \multirow[b]{3}{*}{ Model } & \multicolumn{3}{|c|}{ Coefficients $^{\mathrm{a}}$} & \multirow[b]{3}{*}{$\mathrm{t}$} & \\
\hline & $\begin{array}{r}\text { Unsta } \\
\text { Coe }\end{array}$ & $\begin{array}{l}\text { ardized } \\
\text { cients }\end{array}$ & $\begin{array}{l}\text { Standardized } \\
\text { Coefficients }\end{array}$ & & \multirow{2}{*}{ Sig. } \\
\hline & B & Std. Error & Beta & & \\
\hline 1 (Constant) & 11,557 & 2,797 & & 4,132 &, 000 \\
\hline
\end{tabular}




\begin{tabular}{|c|c|c|c|}
\hline $\begin{array}{l}\text { Sistem Informasi Akuntansi } \\
\mathrm{X} 1\end{array}$ & , 485 & ,138 & 283 3,518, 001 \\
\hline Teknologi Informasi X2 & .280 & .083 & $\begin{array}{lll}.282 & 3.371 \quad .001\end{array}$ \\
\hline $\begin{array}{l}\text { Sistem Pengendalian Internal } \\
\text { X3 }\end{array}$ & ,320 & ,087 & 331 3,679, 000 \\
\hline $\begin{array}{l}\text { Kualitas Sumber Daya } \\
\text { Manusia X4 }\end{array}$ & , 194 & ,084 & 022, 204 2,312, \\
\hline
\end{tabular}

$$
\begin{aligned}
& \mathrm{Y}=11.557+0,485 \mathrm{X}_{1}+0,280 \mathrm{X}_{2}+0,320 \mathrm{X}_{3}+0,194 \mathrm{X}_{4}+\mathrm{e} \\
& \text { Keterangan : } \\
& \text { Y : Kualitas Laporan Keuangan } \\
& \text { a : nilai konstanta, yaitu nilai } \mathrm{Y} \text {, jika } \mathrm{X}_{1} \text { dan } \mathrm{X}_{2}=0 \\
& \mathrm{~b}_{1}, \mathrm{~b}_{2} \text { : koefisien regresi, yaitu nilai peningkatan atau penurunan variabel } \\
& \text { Kualitas Laporan Keuangan yang didasarkan variabel Sistem } \\
& \text { Informasi Akuntansi dan Teknologi Informasi } \\
& \mathrm{X}_{1} \quad \text { : Sistem Informasi Akuntansi } \\
& \mathrm{X}_{2} \text { : Teknologi InformasiKesimpulan } \\
& \text { X3 : Sistem Pengendalian Internal } \\
& \text { X4 : Kualitas Sumber Daya Manusia }
\end{aligned}
$$

1. Dari persamaan tersebut dapat dilihat bahwa konstanta $=14.682$ ini menunjukkan bahwa tanpa variable bebas (Sistem Informasi Akuntansi, Teknologi Informasi, Sistem Pengendalian Internal dan Kualitas Sumber Daya Manusia ) maka terjadi peningkatan Kualitas Laporan Keuangan yaitu sebesar nilai konstanta yang di hasilkan 11.557.

2. Koefisien regresi $\mathrm{X} 1=0,485$, artinya setiap peningkatan variable Sistem Informasi Akuntansi akan meningkatkan variable Kualitas Laporan Keuangan sebesar $=0,485$, dengan

\begin{tabular}{|c|c|c|c|c|c|c|}
\hline & & $\begin{array}{r}\text { Ta } \\
\text { Has }\end{array}$ & $\begin{array}{l}\text { el } 12 \\
\text { Uii T }\end{array}$ & & & \\
\hline & & Coet & icients ${ }^{a}$ & & & \\
\hline & & $\begin{array}{l}\text { Unstanc } \\
\text { Coeff }\end{array}$ & $\begin{array}{l}\text { ardized } \\
\text { ients }\end{array}$ & $\begin{array}{l}\text { Standardized } \\
\text { Coefficients }\end{array}$ & & \\
\hline & & B & Std. Error & Beta & $\mathrm{t}$ & Sig. \\
\hline 1 & (Constant) & 11,557 & 2,797 & & 4,132 &, 000 \\
\hline & $\begin{array}{l}\text { Sistem Informasi } \\
\text { Akuntansi X1 }\end{array}$ &, 485 & , 138 & ,283 & 3,518 & 001 \\
\hline
\end{tabular}
menganggap variable lain dalam model konstan.

3. Koefisien regresi $\mathrm{X} 2=0,280$ artinya setiap peningkatan variable Teknologi Informasi sebesar 1 satuan, akan meningkatkan Kualitas Laporan Keuangan sebesar $=0,280$ dengan menganggap variable lain dalam model konstan.

4. Koefisien regresi $\mathrm{X} 3=0,320$ artinya setiap peningkatan variabel sistem pengendalian internal akan meningkatkan variabel Kualitas Laporan Keuangan sebesar $=0,320$ model konstan dianggap variable lain.

5. Koefisien regresi $\mathrm{X} 4=0,194$ dimana setiap peningkatan variabel kualitas laporan keuangan sebesar 1 satuan, akan meningkatkan Kualitas Laporan Keuangan sebesar = 0,194 dengan menganggap variable lain dalam model konstan 


\begin{tabular}{l|l|l|r|r|r}
\hline Teknologi Informasi X2 & .280 & .083 & .282 & 3.371 & .001 \\
\hline $\begin{array}{l}\text { Sistem Pengendalian } \\
\text { Internal X3 }\end{array}$ &, 320 &, 087 &, 331 & 3,679 &, 000 \\
\hline $\begin{array}{l}\text { Kualitas Sumber Daya } \\
\text { Manusia X4 }\end{array}$ &, 194 &, 084 &, 204 & 2,312 &, 022 \\
\hline
\end{tabular}

a. Dependent Variable: Kualitas Laporan Keuangan Y

Sumber hasil olah data SPSS 22

Dengan menggunakan $\mathrm{t}$ tabel sebagai bahan perbandingan dengan tingkat signifikan $>0,05$. Adapun rumus $\mathrm{t}$ tabel yaitu nilai signifikan sebesar 0,05 dibagi $2=0,025$, dengan derajat kebersamaan $\mathrm{df}=\mathrm{n}-\mathrm{k}-1$ atau 142-2-1= 139, maka hasil diperoleh untuk t tabel sebesar 1,977. Dari pengujian diatas diketahui diperoleh nilai $\mathrm{T}$ hitung untuk variabel Sistem Informasi Akuntansi sebesar $=3.518>1,977$ dengan signifikan $0,01<0,05$ nilai signifikan penggunaan sistem. Maka H1 diterima, berarti terdapat pengaruh yang positif antara Sistem Informasi Akuntansi (X1) terhadap Kualitas Laporan Keuangan Pada Instansi Pemerintah Kota Padang.

Untuk variabel Teknologi Informasi terdapat nilai $\mathrm{T}$ hitung sebesar $=3.371>1,977 \mathrm{t}$ tabel sebesar , dengan tingkat nignifikan $0,01<0,05$ nilai signifikan sebesar $0,01<0,05$. Maka H2 diterima, berarti terdapat pengaruh yang positif antara Teknologi Informasi (X2) terhadap Kualitas Laporan Keuangan Pada Instansi Pemerintah Kota Padang.

Untuk variabel Sistem Pengendalian Internal terdapat nilai T hitung sebesar $=3.679>1,977 \mathrm{t}$ tabel sebesar, dengan tingkat nignifikan $0,00<0,05$. Maka $\mathbf{H 3}$ diterima, berarti terdapat pengaruh yang positif antara Sistem Pengendalian Internal (X3) terhadap Kualitas Laporan Keuangan Pada Instansi Pemerintah Kota Padang.

Untuk variabel Kualitas Sumber Daya Manusia terdapat nilai $\mathrm{T}$ hitung sebesar $=$ $2.312>1,977 \mathrm{t}$ tabel sebesar, dengan tingkat nilai signifikan sebesar $0,02<0,05$. Maka H4 diterima, berarti terdapat pengaruh yang positif antara Kualitas Sumber Daya Manusia (X4) terhadap Kualitas Laporan Keuangan Pada Instansi Pemerintah Kota Padang.

Tabel 13

Hasil Koefisien Determinasi (R2) Model Summary

\begin{tabular}{ll|r|r|r} 
Model & R & R Square & \multicolumn{1}{c|}{$\begin{array}{c}\text { Adjusted R } \\
\text { Square }\end{array}$} & $\begin{array}{l}\text { Std. Error of } \\
\text { the Estimate }\end{array}$ \\
\hline 1 &, $629^{\mathrm{a}}$ &, 396 &, 383 & 3,19471 \\
\hline
\end{tabular}

a. Predictors: (Constant), Kualitas Sumber Daya ManusiaX4, Pengendalian Internal X3, Teknologi Informasi X2, Sistem

Informasi Akuntansi X1,

b. Dependent Variable: Kualitas Laporan Keuangan

Uji Adjusted R Square yaitu menunjukkan koefisien determinasi. Angka ini akan diubah ke bentuk persen, yang artinya persentase sumbangan pengaruh variabel independen terhadap variabel dependen. Nilai $\mathrm{R}^{2}$ sebesar 0,396 artinya persentase sumbangan pengaruh variabel Sistem Informasi Akuntansi, Teknologi Informasi, Pengendalian Internal dan Kualitas Sumber Daya Manusia terhadap Kualitas Laporan Keuangan sebesar 31,8 \%. Sedangkan sisanya sebesar 68,2\% dipengaruhi oleh variabel lain yang tidak dimasukan dalam model ini.

\section{Pengaruh Sistem Informasi Akuntansi Terhadap Kualitas Laporan Keuangan}

Dari pengujian yang telah dilakukan maka diperoleh nilai $\mathrm{T}$ hitung untuk variabel Sistem Informasi Akuntansi sebesar $=3.518>1,977$ dengan signifikan $0,01<0,05$ nilai signifikan penggunaan sistem. Maka H1 diterima, berarti terdapat pengaruh yang positif antara Sistem Informasi Akuntansi (X1) terhadap Kualitas Laporan Keuangan Pada Instansi Pemerintah Kota Padang. 
Maka dapat disimpulkan bahwa Sistem Informasi Akuntansi adalah sistem yang memproses data dan transaksi untuk menghasilkan informasi yang berguna bagi perencanaan, pengendalian, dan bisnis dalam arti menghasilkan laporan, informasi atau memungkinkan pemakai untuk melihat data yang tersimpan dan mengendalikan seluruh proses sedemikian rupa sehingga informasi yang dihasilkan akurat dan efisien.

Penelitian ini sama dengan penelitian sebelumnya Menurut penelitian yang dilakukan menurut (Eveline, 2017) dalam penelitiannya menyatakan bahwa Sistem Informasi Akuntansi signifikan pada kualitas laporan keuangan. Menurut (Gafur, 2016) hasil penelitiannya juga menyatakan bahwa system Informasi akuntansi berpengaruh signifikan terhadap kualitas laporan keuangan.

\section{Teknologi Informasi Terhadap Kualitas Laporan Keuangan}

Untuk variabel Teknologi Informasi terdapat nilai $\mathrm{T}$ hitung sebesar $=3.371>1,977 \mathrm{t}$ tabel sebesar, dengan tingkat nignifikan $0,01<0,05$ nilai signifikan kepuasan pengguna sebesar $0,01<$ 0,05. Maka $\mathbf{H 2}$ diterima, berarti terdapat pengaruh yang positif antara Teknologi Informasi (X2) terhadap Kualitas Laporan Keuangan Pada Instansi Pemerintah Kota Padang. Maka dapat disimpulkan bahwa teknologi informasi adalah salah satu faktor yang mempengaruhi kompleksnya institusi sektor publik. Penggunaan teknologi dalam hal ini untuk aplikasi informatika akuntansi di bidang pemerintah pusat dan daerah sangat penting untuk membantu pejabat manajemen keuangan menyiapkan laporan keuangan berbasis kelayakan secara efisien, efektif dan ekonomis berdasarkan standar akuntansi pemerintah.

Menurut Puspita, (2017) Teknologi informasi mempunyai andil yang besar untuk mencapai laporan keuangan yang berkualitas. Teknologi informasi berfungsi sebagai pemrosesan, penyimpanan informasi, dan penyebaran informasi. Menurut Wahyuni et al., (2018) Pemanfaatan teknologi informasi berpengaruh terhadap kualitas laporan keuangan, artinya semakin dimanfaatkannya teknologi informasi maka laporan keuangan akan semakin berkualitas

Menurut Rifandi, (2019) Pemanfaatan teknologi informasi dalam akuntansi dapat mempengaruhi kepuasan para pengguna laporan keuangan karena kualitas, ketepatan, dan keakuratan data yang terkandung dalam laporan keuangan yang telah ditetapkan. Menurut (Widarsono, 2017) pengaruh yang positif terhadap efektivitas penerapan teknologi informasi terhadap kualitas laporan keuangan. Berdasarkan dari sumber penelitian terdahulu yang dikutip empat sumber penelitian terdahulu menunjukkan bahwa Teknologi Informasi berpengaruh signifikan terhadap Kualitas Laporan Keuangan.

\section{Pengaruh sistem pengendalian internal terhadap kualitas laporan keuangan.}

Hasil pengujian secara parsial diketahui bahwa sistem pengendalian internal secara berpengaruh terhadap kualitas laporan keuangan. Nilai t hitung sebesar 3.679 sedangkan t table sebesar1.9771. Maka t hitung lebih besar dari t tabel $(3.679>1.9771)$ dan signifikansi $<0.05(0.000$ $<0.05)$.

Hasil pengujian menunjukkan bahwa hasil penelitian ini sesuai dengan hasil penelitian yang dilakukan oleh (Nunung Suhaeti, Suhendar, 2015), (Eveline, 2016), (Trisnawati, 2018), (Ilat, Ventje, 2015), (Hartono, Arif, 2019) dan (Aditya \& Surjono, 2018) hasil penelitiannya menunjukkan bahwa sistem pengendalian internal berpengaruh positif terhadap kualitas laporan keuangan.

\section{keuangan.}

Pengaruh kualitas sumber daya manusia terhadap kualitas laporan

Pengujian secara parsial diketahui kualitas sumber daya manusia berpengaruh dan signifikan terhadap kualitas laporan keuangan. Nilai t hitung sebesar 2.312 sedangkan $t$ table sebesar 1.97718 maka $t$ hitung lebih besar dari t tabel $(2.312>1.97718)$ dan tingkat signifikansi $<0.05(0.022<$ 0.05). Hasil pengujian ini sejalan dengan hasil penelitian yang dilakukan oleh (Taman, 2017), (Trisnawati, 2018), (Hartono, Arif, 2019), (Sukiati \& Pertami, 2017) dan (Wahyuni, 2018). 


\section{KESIMPULAN}

Berdasarkan penelitian yang telah dilakukan pada Instansi Pemerintah Kota Padang, maka dapat disimpulkan bahwa:

1. Sistem Informasi Akuntansi secara parsial berpengaruh positif terhadap kualitas laporan keuangan di Instansi Pemerintah Kota Padang. Artinya pemberian system informasi akuntansi yang baik oleh Instansi pemerintah kota Padang akan meningkatkan system informasi akuntansi di pemerintah.

2. Teknologi Informasi berpengaruh positif terhadap kualitas laporan keuangan di instansi pemerintah kota Padang. Artinya Penggunaan Teknologi Informasi di Instansi Pemerintah sangat diperlukan dalam memanfaatkan kemajuan teknologi informasi untuk meningkatkan pengelolaan keuangan daerah, dan menyalurkan informasi keuangan daerah ke layanan publik.

3 Sistem Pengendalian Internal secara parsial berpengaruh positif terhadap kualitas laporan keuangan Instansi Pemerintah Kota Padang. Jika Pengendalian internal meningkat dengan baik menghasilkan kualitas laporan keuangan berkualitas, begitu juga sebaliknya. Sehingga hipotesis diterima

4 Kualitas Sumber Daya Manusia berpengaruh positif terhadap kualitas laporan keuangan Instansi Pemerintah Kota Padang. Kualitas laporan keuangan dipengaruhi oleh Sumber sumber daya manusia. Sehingga hipotesis diterima.

\section{E. UCAPAN TERIMA KASIH}

Dengan terselesaikannya penelitian ini, penulis ingin mengucapkan terima kasih kepada pihak-pihak yang turut membantu hingga penelitian ini terselesaikan. Dengan kerendahan hati dan rasa terima kasih saya kepada Instansi Pemerintah Kota Padang

\section{F. DAFTAR PUSTAKA}

Ernawati Fidyah Yuli, M. (2017). Pengaruh Kompetensi Sumber Daya Manusia Dan Sistem Pengendalian Intern Terhadap Kualitas Informasi Laporan Keuangan Dengan Moderasi Pemanfaatan. Jurnal Ilmu Manajemen Dan Akuntansi Terapan (J'MAT), 8(17), 132-153.

Eveline, F. (2017). Pengaruh Sap Berbasis Akrual, Sistem Informasi Akuntansi, Kualitas Sdm, Pengendalian Internal Dan Komitmen Organisasi Terhadap Kualitas Laporan Keuangan Di Badan Nasional Penanggulangan Bencana. Media Riset Akuntansi, Auditing Dan Informasi, 16(1), 1. https://doi.org/10.25105/mraai.v16i1.2004

Gafur, S. D. (2016). Pengaruh Pemanfaatan Sistem Informasi Akuntansi Keuangan Daerah Terhadap Kualitas Laporan Keuangan Pemerintah Daerah Dengan Internal Audit Sebagai Variabel Intervening (Studi Kasus SKPD Se-Kota Kupang). Jurnal Akuntansi, 3(September), $37-49$.

Hanafiah, A. F., \& Zulvia, D. (2018). Analisis Faktor-faktor yang mempengaruhi Kinerja Sistem Informasi Akuntansi (SIA) Di PT. Cipta Niaga Semesta.

Juwita, R. (2018). Pengaruh Implementasi Standar Akuntansi Pemerintahan dan Sistem Informasi Akuntansi Terhadap Kualitas Laporan Keuangan. Trikonomika, 12(2), 201. https://doi.org/10.23969/trikonomika.v12i2.480

Masiaga, N. (2019). The Implication Of Accounting Information System , Financial Performance Measurement And Decision Making Authority To The Performance Accountability (Pengaruh Sistem Informasi Akuntansi, Ukuran Kinerja Keuangan dan Otoritas Pengambilan KeputusanTerhadap A. Accounting Journal, 02, 11-21. 
Nadir, R., \& Hasyim, H. (2018). Pengaruh Pemanfaatan Teknologi Informasi, Kompetensi Sumber Daya Manusia, Terhadap Kualitas Laporan Keuangan Pemerintah Daerah Dengan Variabel Intervening Standar Akuntansi Pemerintahan Berbasis Akrual (Studi Empiris Di Pemda Kabupaten Barru). Akuntabel, 14(1), 57. https://doi.org/10.29264/jakt.v14i1.1007

Puspita, D. H. R. (2017). Pengaruh Kapasitas Sumber Daya Manusia Dan Pemanfaatan Teknologi Informasi Terhadap Kualitas Laporan Keuangan Pemerintah Daerah Dengan Variabel Intervening Spi Pemerintah. Deasy Hary Rahman Puspita, Dewi Amalia, 150-171.

Rifandi, M. (2019). Pengaruh Teknologi Informasi Dan Pengawasan Keuangan Terhadap Nilai Informasi Laporan Keuangan Pemerintah Daerah. Relasi : Jurnal Ekonomi, 14(2), 48-61. https://doi.org/10.31967/relasi.v14i2.263

Saeidi, P., Saeidi, S. P., Sofian, S., Saeidi, S. P., Nilashi, M., \& Mardani, A. (2018). The impact of enterprise risk management on competitive advantage by moderating role of information technology. Computer Standards and Interfaces, 63, 67-82. https://doi.org/10.1016/j.csi.2018.11.009

Sugiyono. (2016). Metode Penelitian Kuantitatif, Kualitatif, dan R\&D.

Wahyuni, S., Fadah, I., \& Tobing, D. S. (2018). Pengaruh Kompetensi Sumber Daya Manusia dan Pemanfaatan Teknologi Informasi Terhadap kualitas Laporan Keuangan Melalui Pengelolaan Barang Milik Daerah. Bisnis Dan Manajemen, 12, 66-80.

Widarsono, A. (2017). Pengaruh Efektivitas Penerapan Teknologi Informasi Terhadap Kualitas Laporan Keuangan Pemerintah Daerah. Jurnal Riset Akuntansi Dan Keuangan, 1(1), 1. https://doi.org/10.17509/jrak.v1i1.6566 